\title{
IEA-ECBCS Annex 51: energy efficient communities. Experience from Denmark
}

\author{
A. Dalla Rosa ${ }^{1, *}$, S. Svendsen ${ }^{2}$ \\ ${ }^{1}$ Technical University of Denmark, Kgs. Lyngby, Denmark \\ ${ }^{2}$ Technical University of Denmark, Kgs. Lyngby, Denmark \\ *Corresponding author. Tel: +45 45251939, Fax: +45 45881755, E-mail: dalla@byg.dtu.dk
}

\begin{abstract}
The paper describes the Danish contribution to the IEA-ECBCS Annex 51: "energy efficient communities”. We present three case studies, two from Annex subtask A (state-of-the-art review) and one from subtask B (ongoing projects). The first case study is "Samsoe: a renewable energy island". In a ten-year period, the community achieved a net $100 \%$ share of renewable energy in its total energy use, relying on available technical solutions, but finding new ways of organizing, financing and owning. The second project is "Concerto class I: Stenloese Syd”. The buildings in the settlement are low-energy buildings class I (Building Regulation 2008). The project envisaged the implementation of selected key energy-supply technologies and building components and carried out an evaluation of user preferences to give suggestions to designers and constructors of low-energy houses. The third case study is: "low-energy neighborhood in Lystrup, Denmark". The project integrates sustainable solutions both for the building sector and the energy supply side, which in the case consists on a low-temperature district heating network. The analysis of the successful/unsuccessful factors in the projects contributes to develop the instruments that are needed to prepare local energy and climate change strategies and supports the planning and implementation of energy-efficient communities.
\end{abstract}

Keywords: energy efficiency, urban planning, renewable energy, district heating

\section{Introduction}

The main objective of the IEA-ECBCS Annex 51: "energy efficient communities" is the design of integrated long-term energy conservation and greenhouse gas (GHG) mitigation strategies within a community, with optimal exploitation of renewable energy (RE) [1]. A holistic approach is used, comprehending generation, supply, transport and use of energy. Annex 51 explores effective paths that implement technical innovations in communities with an increased rate, enabling communities to set up sustainable energy structures and identify the specific actions necessary to reach ambitious goals. We consider both short-term and long-term plans, and their economic feasibility. Furthermore, we prepared recommendations, best-practice examples and background material for designers and decision makers.

\section{Methodology}

The title of subtask A is "existing organizational models, implementation instruments and planning tools for local administrations and developers - a state-of-the-art review”. Each participating country describes the national legislative and economic framework for urban energy and climate change policies and prepared a review of data acquisition methods and tools for monitoring municipal energy and GHG balances. Next, we consider local energy system modeling and simulation tools and their combination with conventional planning tools for the design of energy supply systems and demand calculation. Finally, we discuss successful examples of community energy planning projects within the participating countries. The focus is on methods and planning principle, implementation strategies and the final comparison and evaluation of approaches in different countries.

In subtask B, "case studies on energy planning and implementation strategies for neighborhoods, quarters or municipal areas", we describe methods to characterize the actual state of a project in terms of energy and GHG performance. We investigate scenarios and planning alternatives arisen during the case study timeframe, and we report cost structures and 
cost/benefit analyses. The process organization, the role of the decision makers and the implementation strategy are put into focus. Finally, we report R\&D issues, methods and tools used by the decision makers and the results achieved, with regard to GHG targets and economic feasibility.

\section{Results and Discussion}

\subsection{Samsø: a renewable energy island}

In 1997 Samsø island (114 km², 4124 inhabitant in 2010) won a competition, announced by the Danish Ministry of Energy. It dealt with the choice of a local community with the most feasible plan for the transition to energy self-sufficiency with exploitation of RE.

\subsubsection{Objectives and milestones}

The objective was to study what share of RE a well-defined area could achieve using available technology, and without extraordinary state subsidies. The master plan described the available resources and how the transition could be made, with descriptions of both technical and organizational figures. Reduced energy consumption in all sectors, i.e., heating, electricity and transportation was an essential requirement. The degree of local participation was another top priority for the project: the business community, local authorities and local organizations had to support the proposed master plan to give it credibility. It was expected to envisage new ways of organizing, financing and owning the sub-projects proposed.

Table 1: Comparison between energy and economical figures in Samsø, period 1997-2005.

\begin{tabular}{lcc}
\hline Energy and economical figures & Master Plan (1997) & Achieved (2005) \\
\hline Share of renewable energy [\%] & 100 & 99.7 \\
Degree of energy self-sufficiency [\%] & 100 & 35 \\
Share of district heating [\%] & 65 & 43 \\
Heat use [TJ/year] & $140(+0 \% *)$ & $155(+10 \% *)$ \\
Electricity use (no for heat) [TJ/year] & $70.0\left(-12 \%^{*}\right)$ & $77.3\left(-3 \%^{*}\right)$ \\
Onshore wind turbines [TJ/year] & 86 & 100 \\
Offshore wind turbines [TJ/year] & 260 & 285 \\
$\mathrm{CO}_{2}$ emissions [tons/year] & -14000 & -15000 \\
Private investment [€ $\left.10^{6}\right]$ & 78.7 & 53.3 \\
Public subsidies [€ $\left.10^{6}\right]$ & 9.3 & 4.0 \\
Private investment [€/inhabitant] & 20000 & 13500 \\
Public subsidies [€/inhabitant] & 2300 & 1000 \\
\hline
\end{tabular}

*Reference year: 1997

\subsubsection{Energy conservation}

Campaigns were made concerning energy savings, among those the "pensioner project". The Danish Energy Authority granted funds (50\% of the investment, max. 3250 EUR) to pensioners for energy saving renovations in their private houses. Informative letters were sent to the 444 pensioner families of Samsø and a free visit by an energy adviser was offered. $43 \%$ of the families made use of it. Local business increased its turnover by 1.1 million EUR. Nevertheless, the total energy use (electricity, heat and transport) increased by $4 \%$ in the period 1997-2005, from 305.4 TJ to $318.6 \mathrm{TJ}$, mainly due to an increased heat demand $(+10 \%$, partly because of a cold winter in 2005) and energy use for transportation ( $+7 \%)$.

\subsubsection{Energy supply}

The municipal council guaranteed the mortgage loans that financed the district heating (DH) plants, whose fuel (straw and wood chips) is produced by local farmers. Buildings built in 
areas with existing or planned DH were compelled to connect to the system, while the houses that complied at least with the low-energy class 2 standard (Building Regulation 98, [2]) were exempt. Outside $\mathrm{DH}$ areas, the actual planning process began when $70 \%$ of consumers using regular oil furnaces or boilers had signed up for the conversion to DH. The energy utilities introduced a new financial model, who was an exception to normal practice. The consumer paid a connection fee of around 10 EUR, if registered before the establishment of the network, while the fee increased up to 5000 EUR afterwards. This method guaranteed a high degree of connection and aimed at encouraging end-users' energy savings, due to higher energy supply costs. The production increased from 39.6 TJ in 1997 to 82.4 TJ in 2005 [3]; at the same time, the expansion of the existing networks caused the distribution heat losses to increase from $19.9 \%$ to $24.2 \%$ of the delivered energy. The main figures about the $\mathrm{DH}$ systems are shown in Table 2. A cooperatively owned regional utility, NRGi, own and operates two DH systems; another system is owned by a local commercial operator, while the consumers themselves own and finance the last system.

Table 2: District heating in Samsø (2005).

\begin{tabular}{|c|c|c|c|c|}
\hline Location & Nordby/Mårup & Tranebjerg & Ballen/Brundby & Onsbjerg \\
\hline Ownership & NRGi* & NRGi* & Consumer-owned & Private \\
\hline Consumers & 178 & 400 & 240 & 76 \\
\hline Investment costs $\left[€^{*} 10^{6}\right]$ & 2.7 & 3.5 & 2.2 & 1.1 \\
\hline Subsidy $\left[€^{*} 10^{6}\right]$ & 1.2 & - & 0.3 & 0.4 \\
\hline Peak power [MW] & 1.6 & 3.0 & 1.6 & 0.8 \\
\hline Energy [MWh/year] & n.a. & 9500 & 3300 & 1500 \\
\hline Solar collector area $\left[\mathrm{m}^{2}\right]$ & 2500 & - & - & - \\
\hline Solar storage tank [m³] & 800 & - & - & - \\
\hline Year of establishment & 2002 & 1993 & 2005 & 2002 \\
\hline Resources & Biomass/ solar & Biomass & Biomass & Biomass \\
\hline Fuel consumption [tons/year] & 1250 & n.a. & 1200 & 600 \\
\hline Fixed fee $[€ /($ consumeryear $)]$ & 344 & 362 & 345 & 350 \\
\hline Price $[€ / \mathbf{M W}]$ & 92 & 104 & 90 & 90 \\
\hline Connection fee $^{*}[€]$ & 3350 & 3350 & 6000 & 6000 \\
\hline Connection fee* $\left[€ / m_{\text {pipe }}\right]$ & 150 & 150 & - & - \\
\hline
\end{tabular}

Only for customers who connect after the establishment of the DH network

Individual solutions were applied in areas not reached by DH networks: 860 solar thermal systems, 35 heat pumps and 120 biomass-based units were installed [4]. To cover the electricity demand, 11 onshore wind turbines were installed, with a total peak capacity of 9 $\mathrm{MW}_{\mathrm{el}}$. An offshore wind turbines park was dimensioned with a capacity of $23 \mathrm{MW}_{\mathrm{el}}$, corresponding to the difference between the actual energy use in the transport sector and the energy savings to be realized in the master plan. Five of the 10 off-shore wind turbines are owned by the municipality of Samsø. The proceeds from the windmills are reinvested in future energy projects as Danish law does not allow local municipalities to earn money by generating energy. Three of the off-shore turbines are privately owned by local farmers. Nine offshore wind turbines are owned privately by small groups of farmers and two are owned by local cooperatives with up to 1500 shareholders [5]. Spreading the ownership improved citizenship acceptance for the construction of the wind turbines. Electricity production prices are regulated by law and include a ten-year fixed price agreement which is the same for all the wind turbines on the island. The agreement stipulates a guaranteed price of about 0.08 EUR for the first 12000 full-load running hours and afterward about $0.06 \mathrm{EUR}$, until the ten year period expires. 


\subsubsection{Analysis}

The strengths, weaknesses, opportunities, and threats (SWOT) analysis is shown in Table 3.

Table 3: SWOT analysis for the Samsø case study.

\begin{tabular}{|c|c|c|}
\hline & Helpful & Harmful \\
\hline 范 & $\begin{array}{l}\text { Strength } \\
\text { - Political support } \\
\text { - Internal energy market } \\
\text { - Local coordination } \\
\text { - Local ownership } \\
\text { - Organizational structure } \\
\text { - Local resources } \\
\text { - Challenging jobs }\end{array}$ & $\begin{array}{l}\text { Weakness } \\
\text { - Minor energy savings } \\
\text { - No cogeneration } \\
\text { - Municipality administration } \\
\text { - Uncertainty of energy prices } \\
\text { - Training and education } \\
\text { - Protests against placement of wind } \\
\text { generators and DH plants }\end{array}$ \\
\hline . & $\begin{array}{l}\text { Opportunity } \\
\text { - External investments } \\
\text { - EU incentives } \\
\text { - Lower tax for electricity from RE } \\
\text { - Creation of new employment opportunities } \\
\text { - El. contracts avoid price fluctuations } \\
\text { - Positive effect on tourism }\end{array}$ & $\begin{array}{l}\text { Threat } \\
\text { - Removal of subsidies by new } \\
\text { government } \\
\text { - Immaturity of electric car technology } \\
\text { - Lack of suppliers and companies for } \\
\text { maintenance }\end{array}$ \\
\hline
\end{tabular}

\subsection{Concerto class I: Stenløse Syd}

The project Class1 began in 2007, after the municipality of Egedal decided to strengthen the energy requirements for a new settlement to be erected in the municipality [6]. The project is part of the "EU Concerto initiative project" [7]. During the years 2007-2011 a total of 442 dwellings were or are designed and constructed with a heating demand corresponding to the Danish "low-energy class I". This means that the energy consumption will be $50 \%$ below the energy frame set by the Danish Building Regulation (DBR 08). The energy frame is calculated with the following formula, where $\mathrm{A}$ is the heated floor area:
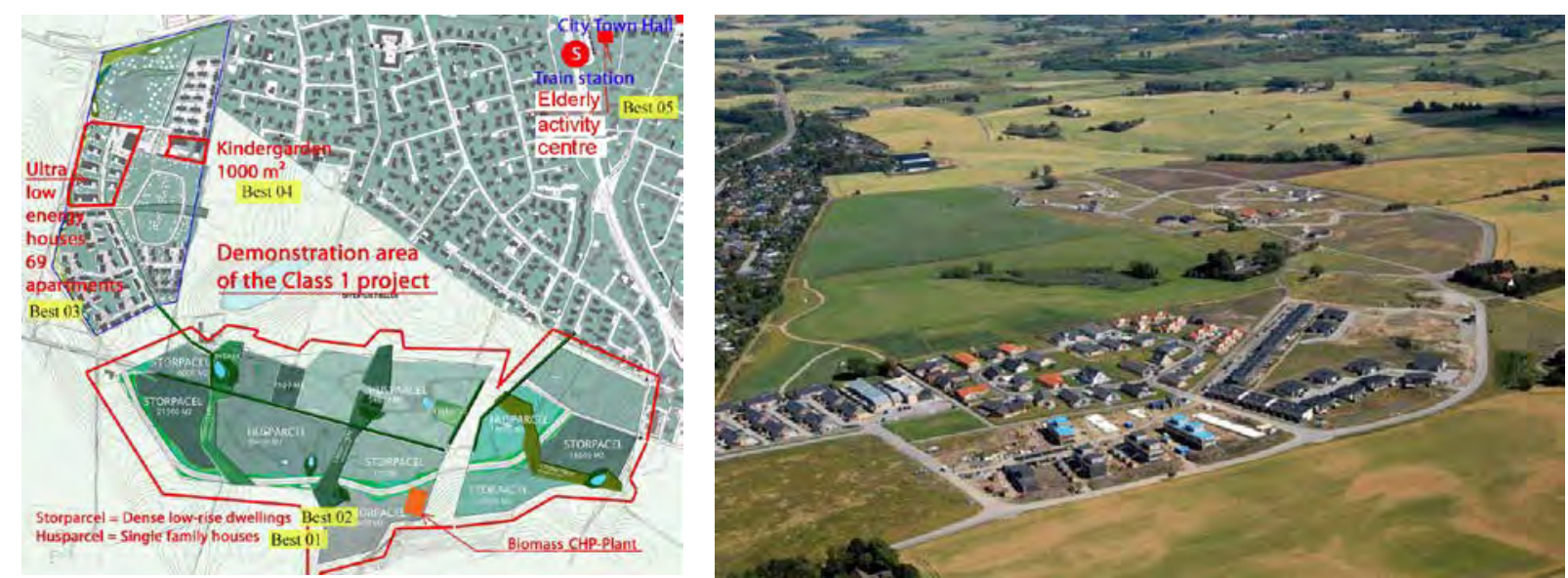

Figure 1: Site area (left) and status of the settlement in 2010 (right).

During the first year of the project, the municipality itself has constructed a kindergarten in compliance with the above restrictions and a social housing association has completed an ultra low-energy house project (heating demand of $15 \mathrm{kWh} /(\mathrm{m} 2$.year)) - comprising 65 
dwellings. Besides, the constructions of the elderly centre and 13 single family houses have commenced. The Class 1 project focuses on selected key technologies and building components: slab and foundation insulation, window frames, mechanical ventilation with heat-recovery combined with heat-pumps, biomass-CHP, heat distribution for local DH and user-friendly building energy management systems.

\subsubsection{Evaluation of user preferences and legislative analysis}

One part of the demonstration activities deals with the evaluation of the user preferences to improve target future buyers/builders of low-energy houses. The methodology was determined and the initial interviews were carried out. The final report is available in [6]. Proactive attempts have been identified and documented to understand legislative and planning means in the process of promoting sustainable community projects [8].

\subsubsection{Key-product development}

Industrial partners have made progress in developing new and/or improved products suitable to low-energy buildings: a low energy window, whose production costs were reduced by $30 \%$ by process changes and machinery investment and a ventilation unit with heat recovery and integrated heat pump for low-energy houses. Moreover the low-rise, dense building sites will be supplied by a local low-temperature DH network. During the summer period the bio-mass CHP plant will be closed down and the solar heating systems will deliver the heat for domestic hot water (DHW).

Table 4: SWOT analysis for the Stenløse Syd case study.

\begin{tabular}{|c|c|c|}
\hline & Helpful & Harmful \\
\hline 莬 & $\begin{array}{l}\text { Strength } \\
\text { - Integration of different sectors } \\
\text { - Comparison of strategies in the different } \\
\text { participating countries }\end{array}$ & $\begin{array}{c}\text { Weakness } \\
\text { - No obligatory monitoring concept } \\
\text { implemented in all the sub-projects }\end{array}$ \\
\hline 要 & $\begin{array}{l}\text { Opportunities } \\
\text { - Mix of energy savings and renewable energy } \\
\text { policies, R\&D and dissemination activities } \\
\text { - Intelligent management and monitoring of } \\
\text { water and energy consumption }\end{array}$ & $\begin{array}{c}\text { Threats } \\
\text { - Coordination of many partners }\end{array}$ \\
\hline
\end{tabular}

\subsection{Low-energy neighborhood in Lystrup}

The project deals with the realization and evaluation of a sustainable housing area in Lystrup, Aarhus. The residential area B was completed in "Lærkehaven" in May 2008 and represented the first step towards the vision of a sustainable housing development, with a total of 122 lowenergy buildings. The residential area C was completed in early 2010. The last stage (residential area A) will be finalized in 2011. The main characteristics of each area are [9]: A: 32 two-storey family houses according to the German Passive House Standard.

B: 33 two storey houses (Danish low-energy class I) and 17 single-storey houses (Danish lowenergy class 2), LED lighting, phase change materials (PCM), common solar cell facility.

C: 40 residences (Danish low-energy class I, expected energy demand of $30 \mathrm{kWh} / \mathrm{m}^{2}$, total heated floor area: $4115 \mathrm{~m}^{2}$ ), connected to a low-energy DH network.

In the paper, we focus on the area $\mathrm{C}$. The project integrates sustainable solutions in the enduser side (building sector) and in the energy supply side (DH network). The former deals with finding cost-effective solutions for the construction of low-energy buildings and at the same time promoting high architectural quality and comfort; the latter refers to the demonstration of 
the technical and economical feasibility of $\mathrm{DH}$ applied to areas with low heat demand densities and to the testing of two heating unit designs with focus on return temperature.

\subsubsection{The low-energy and low-exergy district heating system}

The project is among the first in the world, where a low-temperature DH network is applied. The DH network (total trench length: $\sim 800 \mathrm{~m}$ ) was designed according to low-temperature operation in the supply pipe $\left(55^{\circ} \mathrm{C}\right)$ and in the return pipe $\left(25^{\circ} \mathrm{C}\right)$. The application of the lowexergy concept to the DH technology aims at three main targets. The first one is to guarantee comfort, with regards to delivery of DHW and to space heating requirements, by exploiting low-grade energy sources and RE. The second objective is to match the exergy demand of such applications with the necessary exergy available in the supply system, by making the temperature levels of the supply and the demand closer to each other. Finally, it aims at reducing the heat loss in the distribution network, so that the total profitability is ensured from the socio-economic point of view. The main design concepts are:

-Low-size media pipes. This is achieved by allowing a high pressure gradient in the branch pipes connected to the unit with instantaneous DHW preparation or by installing units with storage of $\mathrm{DH}$ water. The latter one consists on a heat exchanger coupled to a water storage tank on the primary side, which ensures low continuous water flow from the $\mathrm{DH}$ network and therefore media pipes of lower size in the distribution lines.

- Low-operational temperatures: down to $50-55^{\circ} \mathrm{C}$ in the supply line and 20 $25^{\circ} \mathrm{C}$ in the return line.

- Twin pipes are used. Furthermore flexible plastic pipes replace steel pipes, wherever it is possible. This leads both to lower investment costs for the civil works connected to the laying of the pipeline and to lower total heat loss.

- Installation of a circulation pump. The pump ensures an increase of the available differential pressure in the network and it compensates for the choice of small-diameter media pipes.

Figure 2: Sketch of the DH network with the location of the meters (adapted from [10]).

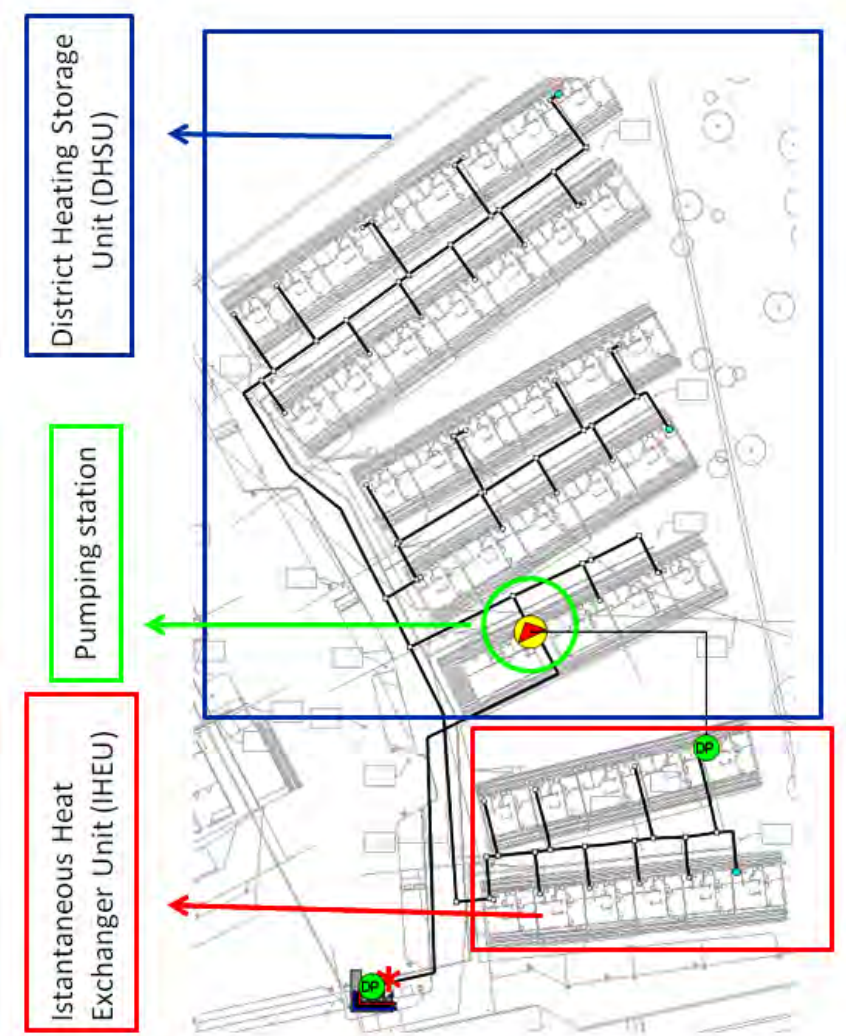

Two types of DH substations are installed: 30 Instantaneous Heat Exchanger Unit (IHEU) and 11 District Heating Storage Unit (DHSU). This former utilizes a heat exchanger between the primary side (DH loop) and the secondary side (DHW loop) for instantaneous production of DHW, while there is a direct system for space heating. The unit is equipped with an external by-pass, meaning that the by-pass water does not flow through the heat exchanger. The latter includes a storage tank and a heat exchanger. Heat is stored with DH fluid as medium. The DHW is produced by a heat exchanger, supplied from the tank. A flow switch detects a water flow and starts the pump. There is no need for by-pass flow in this type of unit. The DHSU are all placed on the same street line so that it is possible to measure both the performance of 
the unit itself and the implications at street level. The total investment cost for the whole network, including the substations, lies between $350000 €$ and $400000 €$.

\subsubsection{Analysis}

We highlight here the main findings, with regards to the planning process.

- The project took profit of the extensive collaboration among different partners: the housing association, industrial partners, architectural and engineering consultants, research institutions and governmental agencies.

- The international architectural competition and the import of prefabricated building envelopes from abroad succeeded to ensure high standards and reasonable economy.

- To some extent, the Danish building construction tradition has been a barrier for planning the community as a whole, more than as a collection of individual building units. In fact, the tendency in the sector, related to low-energy buildings, is to provide solutions based upon individual energy supply systems, mainly heat pumps, and the building types are often not developed with a friendly interface to DH systems. On one hand, this means that standard and reliable offers for low-energy buildings already exist; on the other hand, it could hinder the chance of implementing a sustainable and holistic vision that gathers both the end-user' side and the energy supply side.

- A conflict between different goals arouse during the planning and implementation process. A target pertained to the high expectations about reaching the "climate goal", which for Denmark is defined by the political will of developing an energy system based on $100 \% \mathrm{RE}$ by 2050 and it is translated to action at national, regional and local level. Another objective was connected to the need of finding solutions that can lead the process in a cost-effective way. The conflict was critical at least in two phases: during the definition of the budget for the construction of the low-energy buildings in the residential area $\mathrm{A}$, and during the planning of the energy supply system for the residential area C. In the first case, the maximum allowed budget was constrained by the requirements of the social housing in Denmark, whose requirements limit the economical burden for the tenants. The implementation phase was then delayed and the construction started only when it was decided to exceed the maximum budget. In the preliminary plan for the energy supply system for the residential area $\mathrm{B}$, the planners chose a traditional DH network based on a pair of single pipes, directly connected to the main network in Lystrup $\left(\mathrm{T}_{\text {supply }}=80^{\circ} \mathrm{C}\right.$ and $\left.\mathrm{T}_{\text {return }}=40^{\circ} \mathrm{C}\right)$. The cost-effectiveness of such network was questioned, so that individual solutions, such as heat pumps were considered as alternative. The final decision was taken when an external $R \& D$ project took over the planning responsibility, bringing along also more capital to be invested. The final outcome was successful, since it was demonstrated not only that the low-temperature DH concept is applicable to low-energy buildings, but also that the total long-term economy (30 years) improved in comparison to the original design solutions.

- The recognition of the existence of a market in Denmark in relation to sustainable, energyefficient and environmental-friendly houses was an additional motivation for starting the project, from the housing association point of view. In fact, the completed dwellings were fully occupied by tenants faster than in other newly established areas, despite the housing sector suffered a crisis in that period.

\section{Conclusions}

We conclude by summing up the main findings, which will be extensively discussed in the final report of IEA-ECBCS Annex 51. The case study of Samsø demonstrates how a community can base its whole energy system on RE, without extraordinary external subsidies. The process towards such communities benefits from local participation and local ownership. Taking the results from the experience in Samsø and simply transferring it to a national level, 
the transition towards a fully RE-based nation would cost about 90 billion EUR, giving savings for 8 billion EUR/year and a pay-back time of about 11 years (considering 2005 figures). Although these data are encouraging, the Danish average energy use per inhabitant is 25\% higher than in Samsø, while the potential biomass per inhabitant is one third. Moreover, the potential of wind energy is lower in the rest of the country. Therefore, substantial energy conservation efforts are needed to achieve the goal of $100 \%$ share of RE in the country as a whole. Such issue is central in the project in Stenløse Syd, where proactive attempts have been identified and documented to understand legislative and planning means in the process of promoting sustainable low-energy community projects [8]. With regard to energy planning, the "neighborhood approach" is more profitable and can achieve better results than the "local approach", as demonstrated by the project in Lystrup. The best social-economy is obtained only if the energy plan is done for the community as a whole, instead of considering local plans for the single housing units. Moreover, the combination of energy saving policies in the building sector and an energy efficient supply system based on RE, such as a low-temperature DH network, is seen as a promising concept for achieving ambitious climate goals.

\section{References}

[1] www.annex51.org (2010).

[2] www.ebst.dk (2010)

[3] PlanEnergy and Samsø Energy Academy, Samsø - a renewable energy island, 10 years of development and evaluation, 2007.

[4] J.P. Nielsen, J. Jantzen, Summary of work 2005-2008, Samso Energy Agency, 2009.

[5] www.energiakademiet.dk (2010).

[6] www.class1.dk (2010).

[7] www.concertoplus.eu (2010).

[8] L. Castellazzi, M. Citterio, and others, National guidelines for residential buildings presented as grid of applicability in participating countries, Concerto Class 1 project, Work Package 4, Deliverable 22, 2009.

[9] www.bf-ringgaarden.dk (2010).

[10]Ledningsdimensionering og konceptuelt layout ("Pipe dimensioning and conceptual design”), COWI A/S, 2009. 